\title{
PENGGUNAAN MEDIA AQUAPONIK DALAM MENINGKATKAN HASIL BELAJAR FILTRASI AIR PADA SISWA KELAS 6 (ENAM)
}

\author{
Istiqomah Aminin \\ SDN Dinoyo 1 \\ Jl. MT. Haryono Nomor 2013 Kota Malang Jawa Timur Indonesia \\ isti.aminin@gmail.com
}

\begin{abstract}
Learning about water filtration that lasts for a long time still causes low learning outcomes. This is in accordance with the results of the daily assessment, as many as $61 \%$ of students scored under Minimum Learning Completeness (KBM). Therefore, in order to improve understanding and learning outcomes of the water filtration process, Aquaponic media was made. The purpose of this study is to describe the use of Aquaponic media in improving water filtration learning outcomes in 6th grade students at Dinoyo Elementary School 1. The design of this study uses a qualitative approach. This research method uses Classroom Action Research developed by Kemmis and McTaggart. The subject of this study was the 6th grade students of Dinoyo 1 Elementary School in 2016/2017 which amounted to 34 people. Data collection is done by observation, interviews, anecdotal notes, documentation and written tests. The indicator of the success of this research is determined through individual and classical completeness. This research was conducted in two cycles. Each cycle consists of 2 meetings. The results showed that at the end of the action there was an increase in the results of water filtration learning Learning outcomes achieve classical completeness above $78 \%$.
\end{abstract}

Keyword: aquaponic media, learning outcomes, students

\begin{abstract}
Abstrak: Pembelajaran tentang filtrasi air yang berlangsung selama ini masih menyebabkan hasil belajar rendah. Hal ini sesuai dengan hasil penilaian harian, sebanyak $61 \%$ siswa mendapat nilai dibawah Ketuntasan Belajar Minimal (KBM). Oleh karena itu, dalam rangka meningkatkan pemahaman dan hasil belajar tentang proses filtrasi air, dibuatlah media Aquaponik. Tujuan penelitian ini untuk mendeskripsikan penggunaan media Aquaponik dalam meningkatkan hasil belajar filtrasi air pada siswa kelas 6 SDN Dinoyo 1. Desain penelitian ini menggunakan pendekatan kualitatif. Metode penelitian ini menggunakan Penelitian Tindakan Kelas yang dikembangkan oleh Kemmis dan McTaggart. Subjek penelitian ini adalah siswa kelas 6 SDN Dinoyo 1 tahun 2016/2017 yang berjumlah 34 orang. Pengumpulan data dilakukan dengan observasi, wawancara, catatan anekdot, dokumentasi dan tes tulis. Indikator keberhasilan penelitian ini ditentukan melalui ketuntasan individual dan klasikal. Penelitian ini dilakukan dalam dua siklus. Setiap siklus terdiri dari 2 pertemuan. Hasil penelitian menunjukkan pada akhir tindakan terjadi peningkatan hasil belajar filtrasi air. Hasil belajar mencapai ketuntasan klasikal diatas $78 \%$.
\end{abstract}

Kata kunci: media aquaponik, hasil belajar, siswa

Tema Bumiku merupakan salah satu tema dari sembilan tema yang dipelajari pada pembelajaran kelas VI. Pada pembelajaran tematik Bumiku ini terdapat Kompetensi Dasar yang harus dikuasai oleh siswa. Salah satunya adalah KD. 4.2. Melaksanakan percobaan tentang daur air serta mengidentifikasi variabel bebas dan variabel terikat dalam percobaan tersebut (Anggari, 2015). Salah satu percobaan yang harus dilakukan siswa adalah melakukan percobaan mengolah air limbah kotor menjadi bersih atau filtrasi air.

Pembelajaran filtrasi air yang terjadi di SDN Dinoyo 1 yang terjadi selama ini masih sederhana. Percobaan sederhana tersebut menginstruksikan siswa membuat filtrasi sederhana yang terbuat dari susunan kerikil, sabut kelapa, ijuk, arang dan spons dalam proses penjernihan air kotor atau 
limbah air. Akan tetapi, percobaan dengan filtrasi sederhana ini masih belum optimal dan membuat para siswa kurang atraktif, kurang tertantang dan kurang antusias dan berakibat pada rendahnya hasil belajar tentang filtrasi air.

Berdasarkan hasil Penilaian Harian atau PH pada materi filtrasi air menunjukkan bahwa, sebanyak 24\% siswa mendapat nilai diatas Ketuntasan Belajar Minimal atau KBM, 15\% siswa mendapat nilai sama dengan KBM dan $61 \%$ siswa mendapat nilai di bawah KBM. Sesuai dengan KBM yang berlaku di SDN Dinoyo 1 Malang adalah 75, predikat B, kategori Baik. Oleh karena itu, untuk meningkatkan hasil belajar siswa diperlukanlah sebuah inovasi pembelajaran baru yang membuat siswa merasa tertantang, menyenangkan dan dapat meningkatkan hasil belajar yaitu melalui media aquaponik.

Menurut Usada (2007) media aquaponik merupakan media yang menggabungkan tanaman hidroponik dan air kolam ikan dalam sirkulasinya. Dalam akuaponik, ekskresi hewan diberikan kepada tanaman agar dipecah menjadi nitrat dan nitrit melalui proses alami, dan dimanfaatkan oleh tanaman sebagai nutrisi. Air kemudian bersirkulasi kembali ke sistem akuakultur (Ristiawan, 2012). Media aquaponik dipilih pada pembelajaran ini dikarenakan media aquaponik merupakan media yang dapat mengonkritkan proses filtrasi air. Siswa dapat menyaksikan dan mengamati secara langsung proses filter air. Dengan demikian, siswa dapat menjadi lebih paham dan hasil belajar menjadi lebuh maksimal.

Hasil belajar merupakan tingkat penguasaan yang dicapai oleh pelajar dalam mengikuti program belajar mengajar sesuai dengan tujuan pendidikan. Hasil belajar dalam kerangka studi ini meliputi kawasan kognitif, afektif, dan kemampuan belajar seorang pelajar (Daryanto, 2008). Hasil belajar merupakan keluaran dari suatu pemprosesan masukan. Masukan dari sistem tersebut berupa bermacam-macam informasi sedangkan keluarannya adalah perbuatannya atau kinerja. Perbuatan merupakan petunjuk bahwa proses belajar telah terjadi dan hasil belajar dapat dikelompokkan kedalam dua macam saja yaitu pengetahuan dan keterampilan (Sudjana dan Ibrahim, 2007).

\section{METODE}

Penelitian ini menggunakan penelitian tindakan kelas. Penelitian Tindakan Kelas merupakan proses investigasi terkendali dalam menemukan dan memecahkan masalah pembelajaran yang terjadi di kelas, proses pemecahan masalah dilakukan secara bersiklus, dengan tujuan untuk meningkatkan kualitas pembelajaran dan hasil pembelajaran di kelas tertentu (Akbar, 2010).

Gambaran penelitian tindakan kelas menggunakan siklus yang dikembangkan oleh Kemmis dan McTaggart seperti gambar dibawah ini.

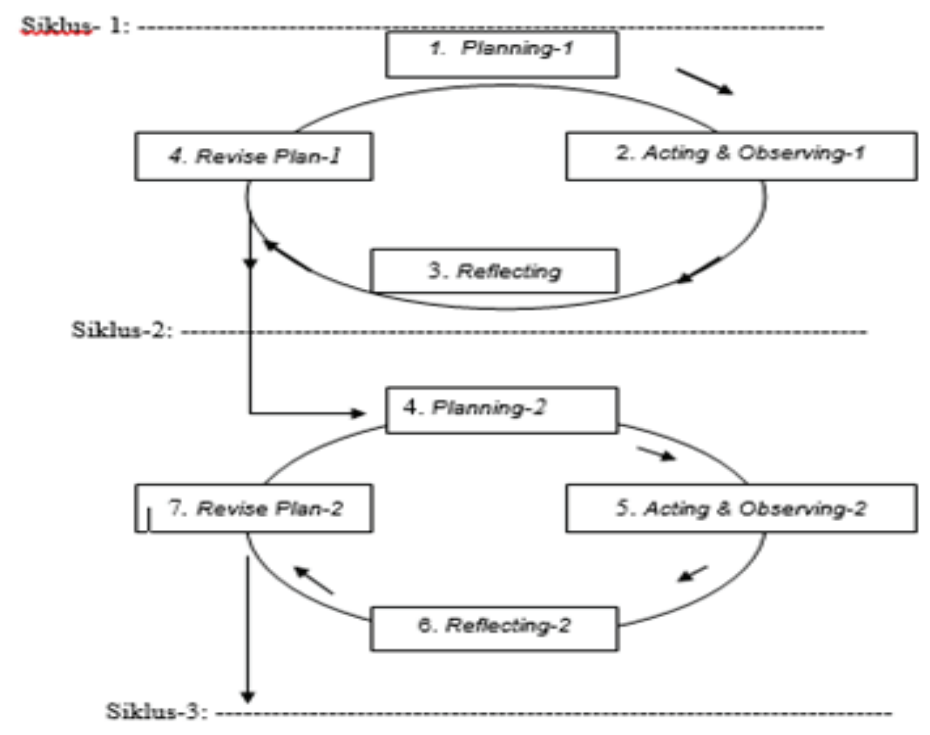

Gambar 1 Alur pelaksanaan tindakan dalam PTK 
Metode pengumpulan data terdiri atas observasi aktivitas belajar siswa selama dan sesudah percobaan, wawancara untuk menggali respon siswa belajar dengan menggunakan media aquaponik, catatan anekdot untuk mengamati belajar siswa dengan menggunakan media aquaponik, dokumentasi dan tes tulis. Instrumen penelitian yang digunakan adalah lembar observasi, pedoman wawancara dan jurnal catatan anekdot. Subjek penelitian menggunakan 34 siswa kelas 6 yang terdiri dari 18 siswa lakilaki dan 16 siswa perempuan dengan kemampuan yang heterogen. Penelitian ini dilaksanakan pada bulan Januari sampai Februari 2017.

Data yang telah terkumpul akan dianalisis secara deskriptif, baik deskriptif kuantitatif maupun deskriptif kualitatif. Data yang dianalisis secara deskriptif kuantitatif adalah data tentang tes tulis materi filtrasi air yang dinyatakan dengan skor atau nilai yang dicapai siswa.

Data kualitatif berupa hasil observasi, wawancara, jurnal catatan anekdot dan dokumentasi akan dianalisis dengan analisis kualitatif. Analisis tersebut dilakukan melalui tahapan: pemaparan data, penyederhanaan data, pengelompokan data sesuai fokus masalah, dan pemaknaan. Dalam proses analisis data, untuk memperoleh data yang benar-benar dapat dipercaya kebenarannya, maka peneliti akan melakukan member check (pengecekan anggota/ subjek penelitian), triangulasi-check and recheck dari segi sumber data/subjek dan metode, perpanjangan pengamatan, dan pelacakan data secara mendalam.

Indikator keberhasilan dari peningkatan hasil belajar siswa dapat dilihat dari hasil tes. Hasil belajar dinyatakan meningkat apabila skor siswa mengalami peningkatan dari sebelum tindakan dan setelah diberi tindakan. Adapun peningkatan hasil belajar dapat diukur sebagai berikut: peningkatan individual, hasil belajar siswa dikatakan meningkat jika skor siswa mengalami peningkatan dari sebelum tindakan dan setelah diberi tindakan. Apabila skor ketercapaian siswa mencapai $>75$, maka siswa tersebut dapat dikategorikan hasil belajarnya meningkat. Peningkatan hasil belajar secara klasikal, diperoleh dari banyaknya siswa yang mendapat nilai diatas $\geq 75$ dibagi dengan banyaknya siswa yang mengikuti tes dikali $100 \%$. Suatu kelas dapat dikatakan meningkat hasil belajarnya, jika $70 \%$ jumlah siswa dalam kelas sudah mencapai nilai 75 ke atas. Apabila taraf penguasaan kelas sudah mencapai 70\%, maka dapat dikatakan bahwa pembelajaran yang dilaksanakan guru dalam meningkatkan hasil beajar pada kelas tersebut telah berhasil. Kemudian sebaliknya, jika taraf penguasaan kelas kurang dari $70 \%$, maka dikatakan belum berhasil.

Pelaksanaan PTK direncanakan selama dua siklus. Siklus pertama dimulai dengan tahap perencanaan. Pada tahap ini diawali dengan refleksi peneliti tentang pembelajaran yang telah dilakukan pada tema Bumiku, menyiapkan lembar observasi dan wawancara, menyiapkan media aquaponik, menyiapkan RPP, membuat LK dan membuat soal evaluasi. Tahap selanjutnya adalah pelaksanaan atau tindakan. PTK ini dilaksanakan selama dua siklus. Pada siklus I akan dilakukan 2 kali pembelajaran (PB). Pelaksanaan tindakan di siklus II dibuat setelah dilakukan refleksi dan evaluasi pada siklus I. Tahap selanjutnya adalah pengamatan. Kegiatan pengamatan ini adalah untuk mengamati perilaku siswa selama kegiatan pembelajaran, dan mengidentifikasi kendalakendala siswa selama mengikuti pembelajaran. Kegiatan pengamatan dilakukan oleh peneliti. Kegiatan pengamatan pada siswa menggunakan catatan anekdot. Selanjutnya adalah tahap refleksi. Pada tahap ini, peneliti menganalisis hasil pengamatan untuk mencari kelebihan dan kekurangan selama tahap pelaksanaan.

\section{HASIL DAN PEMBAHASAN}

\section{Siklus I}

\section{Pelaksanaan}

Pelaksanaan pembelajaran siklus I dimulai tanggal 9 - 23 Januari 2017. Pembelajaran dibuka dengan membaca doa, asmaul husna, salam, menyanyikan lagu Indonesia Raya dan presensi. Sebelum pembelajaran dimulai, siswa diperintahkan untuk membaca buku cerita fiksi 
yang ada pada sudut baca ruang kelas VI selama 15 menit. Kemudian guru memberikan apersepsi atau mengetahui pengetahuan awal yang dimiliki siswa. Siswa bertanya jawab bersama guru tentang proses filtrasi air. Kemudian, guru mengajak siswa ke halaman sekolah untuk mengamati proses filtrasi air pada media aquaponik. Tampak semua siswa terlihat antusias dan penasaran dengan media yang dibawa guru. Antusias siswa dapat terlihat dengan beberapa siswa mau ke depan untuk melihat media aquaponik.

Guru mengkondisikan siswa untuk tetap fokus pada pelajaran. Selanjutnya siswa memperhatikan informasi tujuan pembelajaran yang akan dicapai. Siswa memperhatikan informasi langkah-langkah pembelajaran. Kegiatan awal menerapkan komponen pertama, yaitu mengamati. Sebelum memulai kegiatan mengamati, guruterlebih dahulu memperkenalkan media aquaponik.

Kegiatan selanjutnya guru memerintahkan siswa untuk mengamati bagian-bagian yang ada pada media aquaponik. Kegiatan siswa selanjutnya adalah tahap menanya. Siswa diinstruksikan untuk membuat dua kalimat tanya yang berkaitan dengan bagian-bagian pada media aquaponik, kemudian saling bertukar pertanyaan dengan teman dalam kelompok. Masing-masing siswa dapat melihat dan bergantian menjawab dari pertanyaan teman yang lain. Kegiatan selanjutnya adalah mencoba dan menalar. Dalam kegiatan ini guru memulai dengan membagi siswa menjadi 6 kelompok yang terdiri 5-6 anggota. Kemudian guru memberikan lembar kegiatan kelompok (LKK) pada masing-masing kelompok. Semua siswa dalam kelompok harus bekerjasama. Berdasarkan hasil observasi, ketua kelompok paling dominan dalam mengerjakan tugas kelompok, sedangkan anggota kelompok hanya menulis hasil diskusi. Melihat kondisi seperti ini, guru menyarankan agar siswa yang sudah paham tentang cara menyelesaikan soal cerita agar mengimbaskan kepada anggota kelompok lain. Sehingga diskusinya tidak menjadi satu arah saja. Setelah menuliskan jawabannya, siswa diinstruksikan untuk membaca ulang jawaban sedangkan anggota kelompok lain ikut mendengar, menimbang dan mengecek hasil diskusi.

Setelah mengevaluasi hasil diskusi kelompok, siswa melaksanakan tahap belajar yaitu mengkomunikasikan. Perwakilan dari 2 kelompok mempresentasikan hasil diskusinya kepada teman yang lain. Pada saat mempresentasikan hasil kelompok, penyaji dapat menggunakan media aquaponik. Sedangkan kelompok lainnya memberikan tanggapan dari hasil yang disampaikan oleh penyaji. Pembelajaran dilanjutkan dengan mengajak siswa untuk membuat kesimpulan materi tentang bagian-bagian media aquaponik.

Kegiatan selanjutnya guru melakukan refleksi terhadap materi yang sudah dipelajari. Hasil belajar tentang bagian-bagian pada media aquaponik. Siswa mengerjakan dengan batas waktu yang sudah ditentukan, yaitu 30 menit. Setelah siswa mengerjakan tes evaluasi, guru menanyakan tentang kesulitan apa dalam mempelajari materi siswa. Sebelum kegiatan pembelajaran diakhiri, guru memberikan tugas rumah dengan membaca buku siswa untuk pembelajaran selanjutnya. Akhir kegiatan pembelajaran diakhiri guru dengan doa dan salam.

\section{Observasi}

Observasi pada siklus I ini dilaksanakan selama kegiatan pembelajaran berlangsung. Adapun keterlaksanaan pembelajaran dengan menggunakan media aquaponik pada siklus I yang dilaksanakan oleh guru dikategorikan cukup dengan taraf keberhasilan 78,33\%. 
Tabel 1 Hasil Observasi Keterlaksanaan Pembelajaran oleh Guru Siklus I

\begin{tabular}{|c|c|c|c|c|c|c|}
\hline \multirow{2}{*}{ Tahap } & \multirow{2}{*}{ Indikator } & \multirow{2}{*}{ Deskriptor } & \multirow{2}{*}{$\begin{array}{c}\text { Skor } \\
\text { Maksi- } \\
\text { mal }\end{array}$} & \multicolumn{3}{|c|}{$\begin{array}{l}\text { Skor Perole- } \\
\text { han }\end{array}$} \\
\hline & & & & 3 & 2 & $\mathbf{1}$ \\
\hline \multirow[t]{4}{*}{$\begin{array}{l}\text { Pendahu- } \\
\text { luan }\end{array}$} & $\begin{array}{l}\text { Memotivasi siswa } \\
\text { untuk siap belajar }\end{array}$ & a. Membuka pelajaran & 3 & 3 & & \\
\hline & & $\begin{array}{l}\text { b. Mengaitkan materi dengan pengeta- } \\
\text { huan yang dimiliki siswa }\end{array}$ & 3 & & 2 & \\
\hline & & c. Menyampaikan tujuan pembelajaran & 3 & & 2 & \\
\hline & & $\begin{array}{l}\text { d. Menyampaikan manfaat pembelaja- } \\
\text { ran dalam kehidupan sehari-hari }\end{array}$ & 3 & & & 1 \\
\hline \multirow[t]{4}{*}{$\begin{array}{l}\text { Penyajian } \\
\text { Kelas }\end{array}$} & $\begin{array}{l}\text { Menyampaikan } \\
\text { materi }\end{array}$ & a. Menyampaikan materi & 3 & 3 & & \\
\hline & & $\begin{array}{l}\text { b. Menyampaikan materi menggu- } \\
\text { nakan media aquaponik }\end{array}$ & 3 & 3 & & \\
\hline & & $\begin{array}{l}\text { c. Menggunakan kalimat yang mudah } \\
\text { dipahami siswa }\end{array}$ & 3 & & 2 & \\
\hline & & $\begin{array}{l}\text { d. Memberi kesempatan siswa untuk } \\
\text { bertanya }\end{array}$ & 3 & & 2 & \\
\hline \multirow[t]{3}{*}{$\begin{array}{l}\text { Kerja Ke- } \\
\text { lompok }\end{array}$} & $\begin{array}{l}\text { Membentuk Ke- } \\
\text { lompok }\end{array}$ & $\begin{array}{l}\text { a. Membentuk kelompok yang berang- } \\
\text { gotakan 5-6 siswa secara heterogen }\end{array}$ & 3 & 3 & & \\
\hline & & $\begin{array}{l}\text { b. Memberikan penjelasan tentang tata } \\
\text { cara kerja kelompok }\end{array}$ & 3 & & & 1 \\
\hline & & $\begin{array}{l}\text { c. Membagikan lembar kerja kelom- } \\
\text { pok }\end{array}$ & 3 & & 2 & \\
\hline \multirow[t]{3}{*}{ Penyajian } & $\begin{array}{l}\text { Presentasi Hasil } \\
\text { Kelompok }\end{array}$ & $\begin{array}{l}\text { a. Meminta siswa melaporkan hasil } \\
\text { kerja kelompok }\end{array}$ & 3 & 3 & & \\
\hline & & b. Meminta siswa memberi tanggapan & 3 & 3 & & \\
\hline & & $\begin{array}{l}\text { c. Memberi pemantapan hasil kelom- } \\
\text { pok }\end{array}$ & 3 & & 2 & \\
\hline \multirow[t]{3}{*}{ Tes } & $\begin{array}{l}\text { Pemahaman siswa } \\
\text { terhadap materi }\end{array}$ & a. Membagikan lembar kegiatan siswa & 3 & 3 & & \\
\hline & & $\begin{array}{l}\text { b. Menjelaskan manfaat dari menger- } \\
\text { jakan tes }\end{array}$ & 3 & & & 1 \\
\hline & & $\begin{array}{l}\text { c. Meminta mengerjakan soal tes } \\
\text { secara mandiri }\end{array}$ & 3 & 3 & & \\
\hline \multirow[t]{4}{*}{ Penutup } & $\begin{array}{l}\text { Mengakhiri pem- } \\
\text { belajaran }\end{array}$ & $\begin{array}{l}\text { a. Membimbing siswa membuat kes- } \\
\text { impulan }\end{array}$ & 3 & & 2 & \\
\hline & & $\begin{array}{l}\text { b. Membimbing siswa merefleksi } \\
\text { pembelajaran }\end{array}$ & 3 & & 2 & \\
\hline & & c. Melakukan penilaian & 3 & & 2 & \\
\hline & & d. Memberikan tindak lanjut & 3 & & 2 & \\
\hline & & Jumlah & 60 & & 47 & \\
\hline \multicolumn{3}{|c|}{ Ketercapaian Pembelajaran (\%) } & \multicolumn{4}{|c|}{78.33} \\
\hline \multicolumn{3}{|c|}{ Kriteria } & \multicolumn{4}{|c|}{ Cukup } \\
\hline
\end{tabular}


Tabel 2 Persentase Peningkatan Klasikal Hasil Belajar Filtrasi Air Siklus I

\begin{tabular}{cccc}
\hline $\begin{array}{c}\text { Jumlah Siswa Menin- } \\
\text { gkat }\end{array}$ & Persentase Meningkat & $\begin{array}{c}\text { Jumlah Siswa Belum } \\
\text { Meningkat }\end{array}$ & $\begin{array}{c}\text { Persentase Belum } \\
\text { Meningkat }\end{array}$ \\
\hline 23 & 67.64 & 11 & 32.36 \\
\hline
\end{tabular}

Berdasarkan tabel 2, dapat diketahui bahwa siswa yang mengalami peningkatan hasil belajar sejumlah 23 siswa atau 67,64\% dari jumlah siswa keseluruhan 34 siswa. Sedangkan siswa yang belum meningkat sejumlah 11 siswa atau $32,36 \%$ dari jumlah siswa keseluruhan 34 siswa. Hal ini menunjukkan bahwa pembelajaran yang dilaksanakan belum mencapai target yang diinginkan yaitu sebesar 75\%. Mengingat masih belum terpenuhi target yang diinginkan, maka diperlukanlah siklus II.

\section{Refleksi}

Berdasarkan hasil observasi pelaksanaan pembelajaran yang dilaksanakan dan catatan anekdot pada siklus I, peneliti menemukan beberapa hal yang harus diperbaiki diantaranya: 1) Pada pelaksanaan pembelajaran, terdapat beberapa deskriptor yang belum dilakukan guru, diantaranya adalah guru masih kurang dalam menyampaikan manfaat pembelajaran dalam kehidupan sehari-hari; 2) Hasil belajar siswa tentang filtrasi air belum menunjukkan hasil yang maksimal; 3) Penggunaan media aquaponik perlu dibenahi agar siswa tidak berebut; dan 4) Berdasarkan hasil tes untuk mengukur hasil belajar pada siklus I masih perlu ditingkatkan sebab belum memenuhi kriteria keberhasilan dalam meningkatkan hasil belajar, yaitu 67, 64\%.

\section{Siklus II}

\section{Perencanaan}

Pada tahap ini peneliti mempersiapkan perangkat pembelajaran yang terdiri dari RPP siklus II, lembar observasi aktivitas guru siklus II, Lembar pengamatan siklus II, catatan anekdot siklus II dan media aquaponik. Pada siklus II dilaksanakan dengan mengambil temuan positif siklus I dan memperbaiki setiap kekurangan pada siklus I. Setiap temuan yang muncul kemudian didiskusikan dengan kolaborator untuk samasama dianalisis dan dimaknai sehingga ditemukan langkah yang tepat pada tahap pelaksanaan siklus II. Perbaikan-perbaikan tersebut meliputi: pengkondisian kelas, langkah-langkah pembelajaran diperjelas lagi, dan aktivitas guru dalam menggunakan media aquaponik. Siklus II membahas manfaat akar kangkung pada media aquaponik dan proses filtrasi air bagian kedua.

\section{Pelaksanaan}

Kegiatan pra kegiatan, berdoa, membaca asmaul husna, membaca juz 'amma dan menyanyikan lagu Indonesia Raya. Sebelum pembelajaran dimulai, guru mempersilahkan siswa untuk membaca buku cerita fiksi yang tersedia di sudut baca. Pada kegiatan pendahuluan, guru memberikan apersepsi atau mengetahui pengetahuan awal yang dimiliki siswa, dengan tanya jawab tentang materi yang akan dipelajari. Siswa memperhatikan materi yang akan dibahas. Siswa memperhatikan informasi tujuan pembelajaran yang akan dicapai. Selanjutnya siswa memperhatikan informasi langkah-langkah pembelajaran.

Pada kegiatan awal, siswa mengamati media aquaponik. Secara bergantian siswa, mengamati fungsi-fungsi dan proses penjernihan air melalui media aquaponik.Tahap selanjutnya adalah menanya, pada kesempatan kali ini siswa membuat dua kalimat tanya yang berhubungan dengan proses penjernihan air melalui aquaponik. Siswa saling bertukar pertanyaan dan bergantian untuk menjawab.

Kegiatan pembelajaran selanjutnya adalah mencoba dan menalar. Pada kegiatan ini siswa berdiskusi kelompok mengerjakan Lembar Kegiatan Kelompok. Usaiberdiskusi, giliransiswa harus mempresentasikan hasil kelompoknya. Pada tahap ini siswa diasah kemampuannya dalam mengkomunikasikan. Setelah memaparkan hasil diskusi kelompok, kelompok lain yang belum bertugas sebagai penyaji diminta untuk menanggapi. Tanggapan dari kelompok penyaji dengan kelompok penanggap berlangsung cukup aktif. Sesi tanya jawab mulai melebar dan keluar dari tema, oleh karena itu guru mulai mengambil alih jalannya diskusi dan memberi pemantapan materi berdasarkan pertanyaan pada diskusi tadi. 
Kegiatan selanjutnya adalah tes tulis. Kegiatan ini dilaksanakan untuk menguji hasil belajar siswa. Kegiatan selanjutnya guru melakukan refleksi terhadap materi yang sudah dipelajari.

Tabel 3 Hasil Observasi Keterlaksanaan Pembelajaran oleh Guru Siklus II

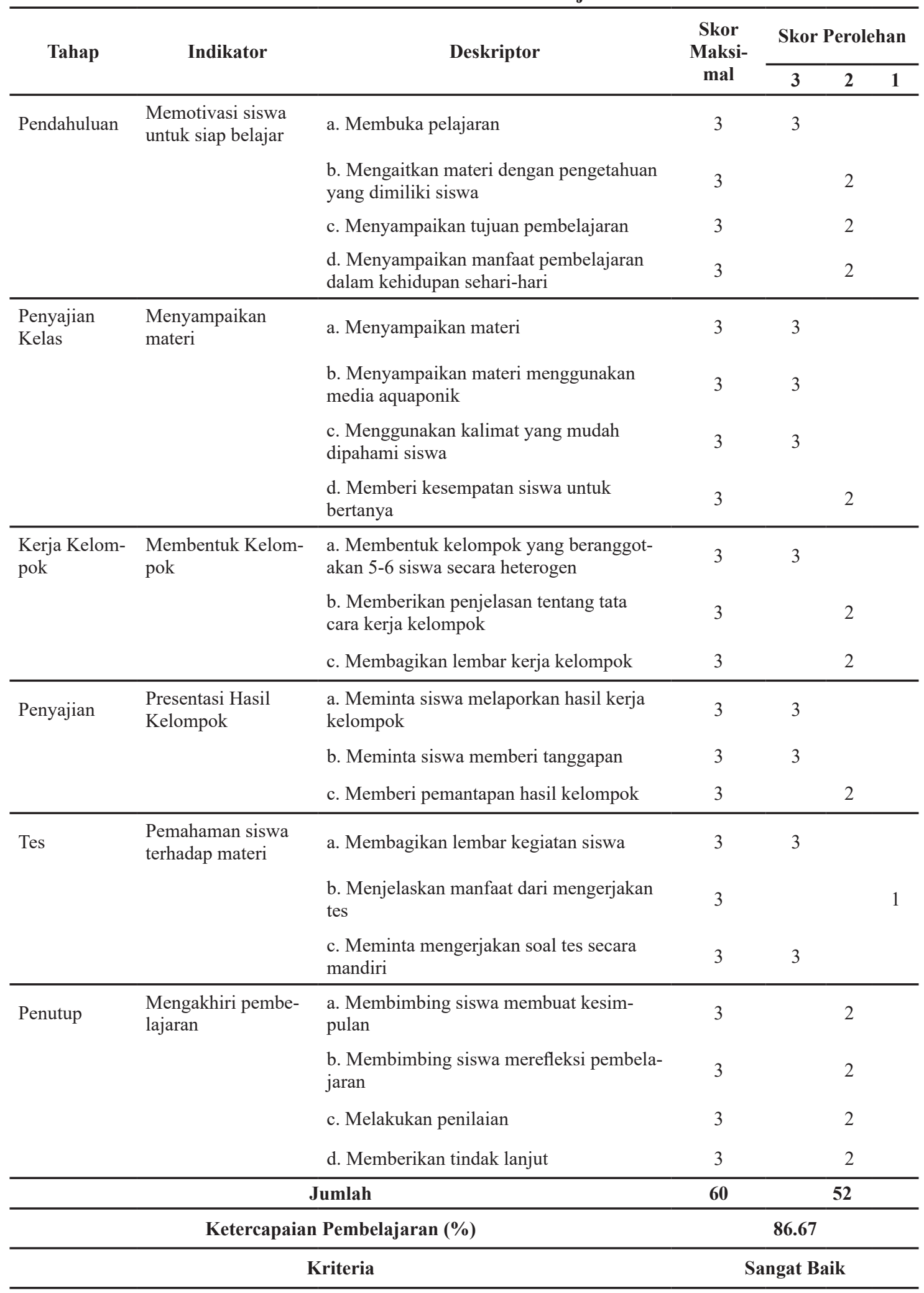

Keterlaksanaan penerapan media pada siklus II tertera pada tabel 3.

\section{Observasi}

\section{(1)}


Berdasarkan tabel 3 dapat diketahui pelaksanaan pembelajaran siklus II yang dilaksanakan oleh guru dikategorikan sangat baik dan berhasil dengan taraf keberhasilan 80,24 \% dalam menerapkan media aquaponik.

Berikut ini disajikan tabel persentase ketuntasan klasikal nilai akhir belajar siswa siklus II.

Tabel 4 Persentase Peningkatan Hasil belajar Pada Siklus II

\begin{tabular}{cccc}
\hline $\begin{array}{c}\text { Jumlah Siswa Menin- } \\
\text { gkat }\end{array}$ & Persentase Meningkat & $\begin{array}{c}\text { Jumlah Siswa Belum } \\
\text { Meningkat }\end{array}$ & $\begin{array}{c}\text { Persentase Belum } \\
\text { Meningkat }\end{array}$ \\
\hline 27 & 79.41 & 7 & 20.59 \\
\hline
\end{tabular}

Berdasarkan tabel 4, dapat diketahui bahwa siswa yang meningkat hasil belajarnya sejumlah 27 siswa atau 79,41 \% dari jumlah siswa keseluruhan 34 siswa. Sedangkan siswa yang belum meningkat sejumlah 7 siswa atau $20,59 \%$ dari jumlah siswa keseluruhan 34 siswa. Hal ini menunjukkan bahwa pembelajaran dengan media aquaponik yang dilaksanakan sudah berhasil sesuai dengan target yang ditentukan. Nilai ratarata hasil belajar mencapai kriteria indikator keberhasilan yaitu diatas 75 .

Berdasarkan paparan data di atas, diperoleh informasi bahwa media aquaponik sudah terlaksana dengan baik dan mencapai hasil yang diinginkan dengan dibuktikan adanya peningkatan hasil belajar siswa. Siswa mulai menunjukkan peningkatan hasil belajar.

Peningkatan hasil belajar yang dicapai baik secara individu maupun klasikal. Persentase peningkatan hasil belajar secara individu pada siklus I adalah $67,64 \%$ meningkat menjadi $78,13 \%$ pada siklus II. Terjadi peningkatan sebesar $11,77 \%$ dari siklus I ke siklus II.

\section{Refleksi}

Berdasarkan catatan anekdot dapat disebutkan bahwa: 1) Guru sudah melaksanakan pembelajaran sesuai dengan RPP. Kekurangan guru terletak pada kurangnya guru dalam memberikan penghargaan kepada siswa yang berhasil menjawab atau menyelesaikan tugas dengan baik; 2) Penggunaan media aquaponik membuat siswa terlihat sangat tertarik dan antusias; 3) Hasil belajar siswa sudah menunjukkan peningkatan di atas skor nilai yang telah ditentukan yaitu 75; dan 4) Indikator keberhasilan yang ditentukan dalam penelitian ini sudah tercapai, sehingga peneliti menghentikan siklus karena peneliti merasa target yang ingin dicapai telah sesuai Kompetensi Dasar yang ditentukan.

Berdasarkan hasil refleksi, lembar observasi, dan lembar penilaian penguasaan materi pada siklus II, catatan anekdot, peneliti mengambil kesimpulan bahwa media aquaponik merupakan media yang sangat efektif bagi siswa yang masih belum paham akan konsep filtrasi air. Media ini sangat membantu siswa dalam mengonkritkan materi yang masih abstrak. Pada media aquaponik, siswa benar-benar mengamati secara langsung jalannya pemfilteran air. Kotoran air diserap oleh akar-akar serabut dari tanaman kangkung, kemudian air bersih digunakan untuk kolam ikan lele. Ikan lele yang setiap hari mengeluarkan kotoran membuat air jernih menjadi keruh lagi, kemudian sirkulasi air diarahkan ke tanaman kangkung.

Peranan media aquaponik memberikan kontribusi yang nyata terhadap meningkatnya hasil belajar. Hal ini sesuai dengan tahap perkembangan kognitif Piaget, bahwa usia siswa kelas 6 SD masuk kepada perkembangan kognitif dari konkret menuju abstrak. Siswa akan lebih tertarik belajar melalui media secara langsung yang akan membantu pemahaman dalam memahami materi fltrasi air.

\section{SIMPULAN}

Berdasar paparan diatas maka dapat disimpulkan bahawa media aquaponik dapat meningkatkan hasil belajar filtrasi air pada siswa kelas 6 SDN Dinoyo 1.

\section{DAFTAR RUJUKAN}

Akbar, Sa'dun. 2010. Penelitian Tindakan Kelas: Filosofi, Metodologi, \& Implementasi. Yogyakarta: Cipta Media Aksara. 
Anggari, Siti Anggie. 2015. Bumiku: Buku Guru Kelas VI. Jakarta: Kementerian Pendidikan dan Kebudayaan

Daryanto. 2008. Evaluasi Pendidikan. Jakarta: Rineka Cipta

Ristiawan, Agung Nugroho. 2012. Aplikasi Teknologi Aquaponic Pada Budidaya Ikan Air Tawar Untuk Optimalisasi Kapasitas Produksi. Jurnal Saintek Perikanan Vol. 8. No. 1, 2012, hal 42-51.
Sudjana, Nana, \& Ibrahim. 2007. Penelitian dan Penilaian Pendidikan. Bandung: Sinar Baru

Usada, Widdi. 2007. Studi Sistem Oksidasi Maju Untuk Perlakuan Air. Prosiding PPI, 243-249. 